Article

\title{
Cadmium Hyperaccumulation and Translocation in Impatiens Glandulifera: From Foe to Friend?
}

\author{
Stephanie Coakley, Gary Cahill, Anne-Marie Enright, Brian O’Rourke and Carloalberto Petti
}

Department of Science and Health, EnviroCORE, Institute of Technology Carlow, Kilkenny Road, R93 V960 Carlow, Ireland; stephanie.coakley@itcarlow.ie (S.C.); gary.cahill@itcarlow.ie (G.C.); anne-marie.enright@itcarlow.ie (A.-M.E.); brian.orourke@itcarlow.ie (B.O.)

* Correspondence: carloalberto.petti@itcarlow.ie; Tel.: +35-359-917-5595

Received: 21 July 2019; Accepted: 10 September 2019; Published: 13 September 2019

check for updates

\begin{abstract}
The use of phytoremediation to sustainably recover areas contaminated by toxic heavy metals such as cadmium (Cd) has been made feasible since the discovery of hyperaccumulator plants. This study examines the potential of the invasive Impatiens glandulifera for phytoremediation propensity of $\mathrm{Cd}$. In these experiments, the plants were exposed to and tested for $\mathrm{Cd}$ accumulation; the propensity to accumulate other heavy metals, such as Zinc, was not investigated. The efficacy of phytoaccumulation was assessed over two trials (Cd concentrations of $20 \mathrm{mg} / \mathrm{kg}$ to $150 \mathrm{mg} / \mathrm{kg}$ ) via examination of bioconcentration factor (BCF), translocation factor (TF), and total removal (TR). Exposure to Cd levels of up to $150 \mathrm{mg} / \mathrm{kg}$ in the trials did not affect the biomass of the plants compared to the control. Impatiens glandulifera accumulated cadmium at a rate of 276 to $1562 \mathrm{mg} / \mathrm{kgin}$ stems, with BCFs, TFs, and TRs of 64.6 to $236.4,0.2$ to 1.2 , and 3.6 to $29.2 \mathrm{mg} \mathrm{Cd}$, respectively. In vitro germination revealed unprecedented germination ability, demonstrating the remarkable hypertolerance of I. glandulifera, with no significant difference in the germination of seedlings exposed to $1000 \mathrm{mg} / \mathrm{kg} \mathrm{Cd}$ compared to the control. This study also examined the localization of $\mathrm{Cd}$ in plant tissues via a histochemical assay using dithizone. The results presented herein suggest that I. glandulifera can act as a hyperaccumulator of $\mathrm{Cd}$ for phytoremediation.
\end{abstract}

Keywords: phytoremediation; heavy metal; bioconcentration factor (BCF); translocation factor (TF); total removal (TR)

\section{Introduction}

Heavy metal contamination resulting from anthropogenic activities is a global environmental concern that poses severe risk to the health of both plants and animals [1]. Cadmium is one of the most important, toxic, and widely distributed pollutants in our environment. Naturally occurring levels of $\mathrm{Cd}$ are typically $<1 \mathrm{mg} / \mathrm{kg}$, but over two centuries of industrialization has led to cadmium levels of over $1000 \mathrm{mg} / \mathrm{kg}$ in some geographical regions [2-5]. Anthropogenic sources of Cd include water discharge from industrial plants, mining and smelting, sewage sludge, and disposal of materials containing heavy metals, e.g., electronics, rechargeable batteries, fertilizers, steel, and pigments $[1,3,6,7]$. In Europe, phosphate fertilizers contribute to Cd levels, with Ireland and the U.K. possessing some of the highest $C d$ levels in soil and sediments. The upper limit for $C d$ levels in soil of $20 \mathrm{mg} / \mathrm{kg}$ can be exceeded for several kilometers surrounding mines or non-ferrous smelters (see Figure 1). 


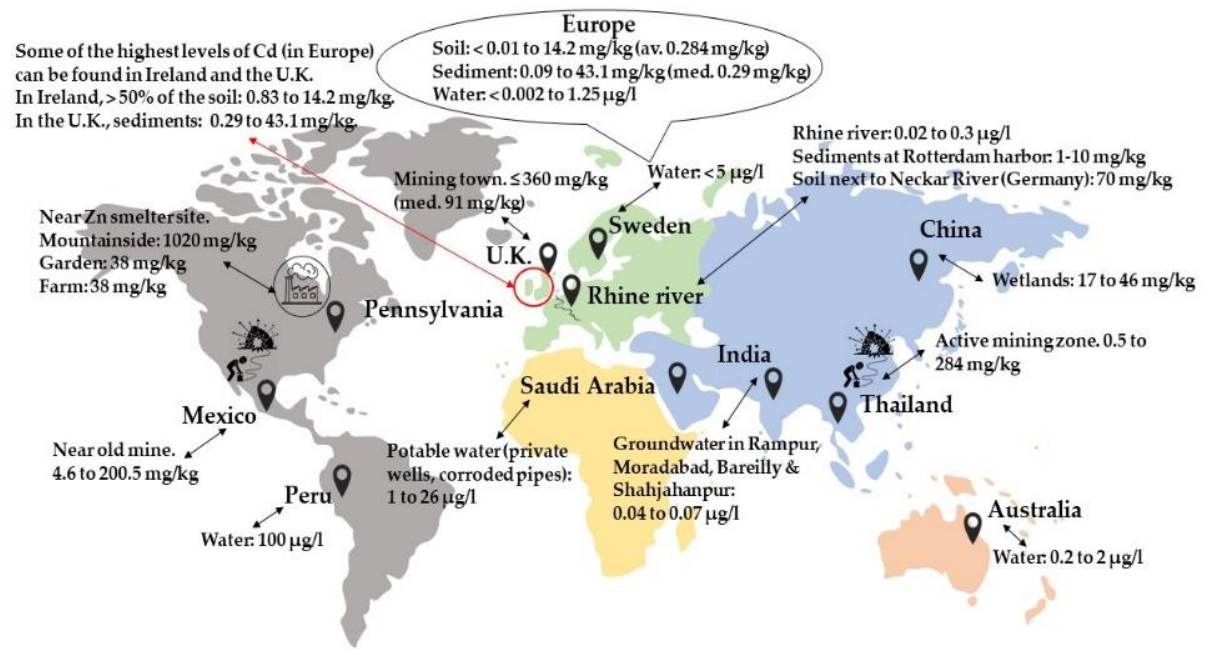

Figure 1. Cadmium (Cd) concentrations in soils, sediments, and water. Average European values are included in the text bubble, while sites with elevated levels of $\mathrm{Cd}$ (due to anthropogenic activities) are denoted by location pins. Mining and smelting are largely responsible for some of the most heavily polluted regions $[4,5,8-14]$.

Cadmium is a non-essential element that can be toxic - and in some cases, lethal - to plants at concentrations as low as $2.5 \mathrm{mg} / \mathrm{kg}$. Cadmium can also reduce plant biomass, the numbers of flowers or fruits, chlorophyll content, and the ability to uptake essential plant nutrients [2,3]. Cadmium is highly mobile, as it has similar physiochemical properties to essential micronutrients such as zinc, enabling it to be readily taken up by plants $[4,15,16]$. Phytoextraction is a form of phytoremediation where pollutants are removed from the soil using plants that can accumulate and bioconcentrate pollutants in its tissues, thereby remediating the soil $[17,18]$. Phytoremediation is a sustainable, efficient, and cost-effective means of rectifying and restoring soil and water to their natural conditions $[4,19]$. The efficacy of phytoremediation is dependent on the properties of the plant, the bioavailability of the heavy metal(s), and the characteristics of the soil $[4,6,20]$. The most suitable phytoremediation plants are fast growing with high biomass production that can tolerate and accumulate high levels of the pollutant. Ideally, these plants ought to be easy to grow and harvest and be resistant to disease and pests $[6,16,18,21]$. In general, phytoaccumulators show an exponential relationship between the heavy metal concentration in their tissues and the concentration of heavy metal in the soil they are grown in $[3,20,22]$.

The term hyperaccumulator was first coined by Brooks and collaborators [23] to describe plants that are hypertolerant and can accumulate elevated concentrations of heavy metals in their aboveground tissues at levels that far exceed those present in the soil. Hyperaccumulator plants possess higher tolerance and accumulation abilities, enhancing the efficacy of phytoremediation [19]. There are reports of over 400 species of hyperaccumulators, though many of these, such as the well-known Cd hyperaccumulator Thlaspi caerulescens, have low biomass or are slow growing [6,22]. Cadmium hyperaccumulators must be capable of accumulating $100 \mathrm{mg} / \mathrm{kg}$ of Cd in its shoots, which is approximately 100 times the level of $\mathrm{Cd}$ that would be found in the tissues of a non-hyperaccumulator species [21,24-26]. Hyperaccumulators should also have a bioconcentration factor and a translocation factor with values greater than unity. The bioconcentration factor (BCF) indicates the efficacy of the plant to accumulate the pollutant in its tissues. The $\mathrm{BCF}$ is calculated as the ratio of concentration of the pollutant in the harvested plant to that of the soil $[25,26]$. The translocation factor represents the plant's ability to translocate the pollutant from the roots to the aerial parts of the plant; it is calculated as the ratio of the concentration of the pollutant in the aerial parts of the plant to the root concentration [26,27]. These factors are utilized to help identify new potential hyperaccumulator species.

Plants vary not only in their tolerance and their accumulation of $\mathrm{Cd}$ but in how they partition $\mathrm{Cd}$ in their various organs and cells $[2,17,28]$. The varied subcellular distribution of $\mathrm{Cd}$ in different organs was 
attributed the responsibility for the high accumulation capacity of Impatiens walleriana $[17,29]$. Plants have evolved various mechanisms to tolerate and mitigate the toxicity of cadmium $[7,15]$. For example, many plants such as Zea mays and I. walleriana compartmentalize Cd in the cell wall of stems as a mechanism of tolerance [7,28-30]. Many of the most effective hyperaccumulators are food crops-for example, Brassica juncea, Helianthus annuus, and Z. mays [26]. However, some ornamental species have been identified as promising sources of new potential phytoremediators [24,25]. For example, recent research has highlighted I. walleriana, the common busy lizzie, as a promising hyperaccumulator of $\mathrm{Cd}$, capable of tolerating up to $120 \mathrm{mg} / \mathrm{kg}$ of $\mathrm{Cd}[20,31,32]$. Impatiens glandulifera was originally introduced as an ornamental species and is now a widespread invasive across Europe and North America. This invasive has been observed along several polluted rivers in the United Kingdom, suggesting a tolerance for the toxicity of environmental pollutants resulting from industry [33]. Impatiens glandulifera displays a high level of phenotypic plasticity, potentially enhancing its ability to adapt to new environments and produce high biomass in a wide range of environmental conditions [34-37]. Additionally, I. glandulifera is considered to be a "transformer", with the ability to alter the ecosystem it invades $[38,39]$. Impatiens glandulifera is the tallest annual invasive in Europe, reaching up to $3 \mathrm{~m}$. This tall plant is fast growing with shallow roots, which makes it easy to harvest [33]. Furthermore, other invasive species such as Eichhornia crassipes, Prosopis glandulosa, and Ipomoea carnea have been identified to have potential use in phytoremediation [40-42].

Considering the species traits in conjunction with the findings of I. walleriana being a hyperaccumulator, the potential of I. glandulifera to tolerate, accumulate, and translocate Cd was hereby investigated. This study is relevant to both Ireland and the U.K. in particular, considering the aforementioned higher levels of $\mathrm{Cd}$ and the widespread invasion of I. glandulifera.

\section{Materials and Methods}

\subsection{Localization of Cadmium in I. glandulifera}

Hydroponic cultures of I. glandulifera were obtained by growing pre-germinated seedlings of I. glandulifera in a modified Hoagland nutrient solution, which did not contain Na-EDTA [43,44]. The modified solution contained only the macronutrients and was adopted from Lombi et al. [45]. Three treatments were utilized: $0 \mathrm{mg} / \mathrm{L} \mathrm{Cd}$ (control), $1 \mathrm{mg} / \mathrm{L} \mathrm{Cd}$, and $10 \mathrm{mg} / \mathrm{L} \mathrm{Cd}$. Twelve seedlings were used in each treatment. Aqueous solutions of $\mathrm{CdPO} 4$ were utilized to supplement the two $\mathrm{Cd}$ treatments 48 hours after being introduced to the modified Hoagland nutrient solution. The seedlings were allowed to grow for seven days. Dithizone (Sigma-Aldrich) was employed to stain $\mathrm{Cd}$ in hand-prepared sections of the roots, the stems, and the leaves of the seedlings. The dithizone staining method was adapted from Clabeaux et al. [46]. Images were captured using a Nikon Eclipse 80i microscope and a Nikon Digital Sight DS-SMc camera.

\subsection{Soil Characteristics}

For the Cd accumulation soils, a homogenized mixture of top soil (Westland Top Soil) and compost (Westland mulitpurpose compost with added John Innes) was employed. Basic soil characteristics were determined after the soil was air-dried, ground, and sieved. Soil characterization included soil texture [47], soil $\mathrm{pH}$ [48], organic carbon [49], total nitrogen, reactive phosphorus, potassium, and cation exchange capacity [50]. Total nitrogen [51], reactive phosphorus (molybdovanadate method) [52] and potassium (tetraphenylborate method) [53] were completed using $\mathrm{HACH}$ working procedures and materials on a HACH Lange DR 6000 Spectrophotometer.

\subsection{Cadmium Trials}

A homogenized mixture of top soil (Westland Top Soil) and compost (Westland multipurpose compost with added John Innes) was employed to plant seedlings (circa two months old) of I. glandulifera in a temperature-controlled glasshouse at a $22 \pm 2{ }^{\circ} \mathrm{C}$ constant temperature in the Institute of Technology 
Carlow, Ireland. A $16 \mathrm{~h}$ light $/ 8 \mathrm{~h}$ dark cycle was employed with a light intensity of $75 \pm 5 \mathrm{Klx}$ maintained for the 12 light hours. Pots were irrigated twice a day with circa $100 \mathrm{~mL}$ of water. Three seedlings were potted in $1 \mathrm{~kg}$ ( $\pm 50 \mathrm{~g}$ ) of the soil/compost (dry weight) in polyethylene pots. Two trials were conducted with four treatments per trial. There were five pots containing a total of 15 plants per treatment in both trials, giving a total of 60 plants per trial. The first treatment from each trial acted as the control and was not spiked with $\mathrm{Cd}$.

Trial One: This trial was utilized as a preliminary estimation of $\mathrm{Cd}$ tolerance; therefore, only primary plant organs (i.e., roots, stems, and leaves) were examined for $\mathrm{Cd}$ accumulation over a nine week trial. A week after the seedlings were planted, treatments $2-4$ were spiked with aqueous solutions of $\mathrm{CdPO}_{4}$. Treatment two was initially spiked to $10 \mathrm{mg} / \mathrm{kg} \mathrm{Cd}$, treatment three to $20 \mathrm{mg} / \mathrm{kg}$, and treatment four to $50 \mathrm{mg} / \mathrm{kg}$. Initially, the concentrations of $10 \mathrm{mg} / \mathrm{kg}$ and $20 \mathrm{mg} / \mathrm{kg}$ were chosen, as these are the lower and the upper threshold values for cadmium, and $50 \mathrm{mg} / \mathrm{kg}(\mathrm{Cd}-50)$ was chosen to represent heavily contaminated soil. However, no injury symptoms were apparent, and the growth of the plants in the spiked soil was comparable to that of the controls. Therefore, the pots in treatments two and three received a second spike, bringing the final soil concentration to $20 \mathrm{mg} / \mathrm{kg}(\mathrm{Cd}-20)$ and $40 \mathrm{mg} / \mathrm{kg}$ (Cd-40). Trial one was harvested (roots, stems, and leaves) after nine weeks.

Trial Two: Stemming from the outcomes of trial one, the second trial was completed using higher concentrations of $\mathrm{Cd}$ in order to examine the extent of the tolerance of I. glandulifera to Cd. Concentrations reflecting heavily polluted regions were chosen: 60, 90, and $150 \mathrm{mg} / \mathrm{kg}$ (Cd-60, Cd-90, and Cd-150, respectively). In trial two, the ability of I. glandulifera to translocate and accumulate $\mathrm{Cd}$ in its flowers was investigated in addition to the primary organs (roots, stems, and leaves). In order to collect sufficient material to assess the levels of $\mathrm{Cd}$ in the flowers, the duration of this trial was extended, and plant materials (roots, stems, leaves, and flowers) were harvested after 11 weeks. Similar to the first trial, a week after the seedlings were planted, the soil was spiked with aqueous solutions of $\mathrm{Cd}$. The $\mathrm{Cd}$ levels were raised to the desired concentrations gradually over the space of a week.

\subsection{Cadmium Analysis}

The harvested plant material was divided into roots, stems (further divided into nodes and internodes), leaves, and flowers. This material was dried overnight at $65{ }^{\circ} \mathrm{C}$ and ground using a Micro-Mill Grinder before acid digestion. The biomass (dry weight, DW) of the plant was recorded. Plant material $(0.5 \mathrm{~g})$ was digested in $10 \mathrm{~mL}$ of $65 \%(w / v)$ nitric acid and $30 \%(w / v)$ hydrogen peroxide (4:1). The samples were incubated overnight at room temperature and were then incubated at $60^{\circ} \mathrm{C}$ for two hours (open vessel digestion). The digested samples were diluted to $50 \mathrm{~mL}$ with deionized water and filtered using filter paper (Whatman Grade 1) and cellulose acetate syringe filters (VWR). The soil was sieved and dried overnight at $65^{\circ} \mathrm{C}$ before acid digestion in $10 \mathrm{~mL}$ of $37 \%(w / v)$ hydrochloric acid and $65 \%(w / v)$ nitric acid (3:1). The soil samples were incubated overnight and then filtered twice using filter paper (Whatman Grade 1) and once using cellulose acetate syringe filters. The levels of cadmium in soil, roots, nodes, internodes, leaves, and flowers were measured using atomic absorption spectrometry (AAS). A 55AA Atomic Absorption Spectrometer (Agilent Technologies) was used in flame mode (air/acetylene) with a coded hollow cathode Cd lamp (Wavelength $228.8 \mathrm{~nm}$, Agilent). The software utilized during AAS analysis was the SpectrAA Version 5.4 (Agilent 55AA). All chemicals were sourced from Scientific and Chemical Supplies.

\subsection{Effect of Cadmium on Germination}

\subsubsection{In Vitro Seed Germination}

To test the effect of $\mathrm{Cd}$ on the germination of seeds of I. glandulifera, the following concentrations were utilized: $0,1000,10,000,20,000,40,000$, and 50,000 mg/kg. The Cd was delivered in $1 \mathrm{~mL}$ of deionized water (i.e., $0,1,10,20,40$, and $50 \mathrm{mg} / \mathrm{mL}$ of $\mathrm{CdPO}_{4}$ ). This experiment was replicated twice, and both trials were conducted at $5{ }^{\circ} \mathrm{C}$ under non-sterile conditions. Seeds of I. glandulifera require 
a cold-wet stratification period to break the dormancy of the seeds. Optimum seed germination for I. glandulifera occurs at $5^{\circ} \mathrm{C}$ [54].

\subsubsection{Pollen Germination}

To determine if the pollen of I. glandulifera could germinate when exposed to Cd, samples of pollen were taken from each of the treatments in trial one and two and were tested for the ability to germinate (in vitro) using liquid pollen germination media, as described in Hussein [55]. After 20 min, the pollen solution was stained using a modified Alexander's stain [56]. Images were captured using a Nikon Eclipse 80i microscope and a Nikon Digital Sight DS-SMc camera.

\subsection{Statistical Analysis}

The biomasses (g DW) of the plants (roots, stems, leaves, and total) across the different $\mathrm{Cd}$ treatments were assessed using one-way ANOVAs on SPSS. Trials one and two were assessed separately. Roots, stems, leaves, and total biomass were assessed independently using one-way ANOVAs. In trial two, the biomass of the flowers across the $\mathrm{Cd}$ treatments was also assessed using a one-way ANOVA on SPSS. Similarly, one-way ANOVAs were also utilized to compare Cd accumulation (roots, stems, and leaves) across treatments. The $\mathrm{Cd}$ accumulation in the flowers of trial two was also assessed using a one-way ANOVA on SPSS. One-way ANOVAs were employed to compare the total removal of $\mathrm{Cd}$ across treatments (roots, stems, leaves, and total). Trials one and two were assessed independently for both $\mathrm{Cd}$ accumulation and total removal of $\mathrm{Cd}$. A one-way ANOVA was utilized to assess the total removal by the flowers harvested from trial two. Pearsons correlation coefficient was employed to assess the interaction between the biomass (g DW) of the plants (roots, stems, leaves, and total) and the total removal of $\mathrm{Cd}$. The significance of the germination success of I. glandulifera was assessed using one-way ANOVA to compare each Cd treatment to the control. All analyses were completed on SPSS, and statistical significance was defined as $\alpha$ value of $\leq 0.05$.

\section{Results and Discussion}

\subsection{Localization of Cadmium}

Cadmium was visible at both concentrations $(1 \mathrm{mg} / \mathrm{L}$ and $10 \mathrm{mg} / \mathrm{L})$ in the roots, the stems, and the leaves, clearly showing the ability of I. glandulifera to translocate and accumulate $\mathrm{Cd}$ in all parts of the plant (Figure 2 presents images from seedlings exposed to $10 \mathrm{mg} / \mathrm{kg}$ ). Indeed, Cd was visible after only one hour, showcasing the ability of I. glandulifera to rapidly translocate this heavy metal. Dithizone complexed $\mathrm{Cd}$ to form a brilliant red with larger precipitates of $\mathrm{Cd}$ staining dark red/black.

Cadmium was highly concentrated in both primary and secondary roots of I. glandulifera; an abundance of large $\mathrm{Cd}$ precipitates were visible (Figure 2, R1 to R3).

Cadmium could be seen in the cells throughout the stems (Figure 2, S1), and it appeared more concentrated in two regions, the first of which comprised the epidermis and the collenchyma directly underneath the epidermis, as seen by the red pigmentation and the larger red/black precipitates and indicated with arrows in Figure 2, S1 to S3. The second region Cd accumulated quite strongly in was the sclerenchyma fibers surrounding the xylem vessels (Figure 2, S3, indicated by arrow at the center of the image), as was expected, as Cd was mobilized via xylem transportation [16,57].

In the leaves, Cd was primarily located in the cells of the petiole (Figure 2, L1 and L3) and the veins. Cadmium accumulation could clearly be seen as bright red pigmentation in leaf epidermal cells (Figure 2, L2), despite the fact that the chlorophyll made visualization of $\mathrm{Cd}$ in the leaves difficult. However, other phytoaccumulators are known to store $\mathrm{Cd}$ in the epidermal cells of the leaves at concentrations four times higher than that of mesophyll cells, presumably to avoid damaging photosynthesis apparatus in the leaf [57].

Most plants compartmentalize $\mathrm{Cd}$ in the cell wall or the vacuole of the roots as a method of tolerating the toxicity of the heavy metal, i.e., to sequester it from the root cytoplasm, preventing 
translocation to the shoots and thereby protecting photosynthesis apparatus $[17,57]$. In I. glandulifera, the $\mathrm{Cd}$ was compartmentalized primarily in the cell wall and was translocated and stored in all plant parts-similar to I. walleriana and other phytoaccumulator plants [28,31].

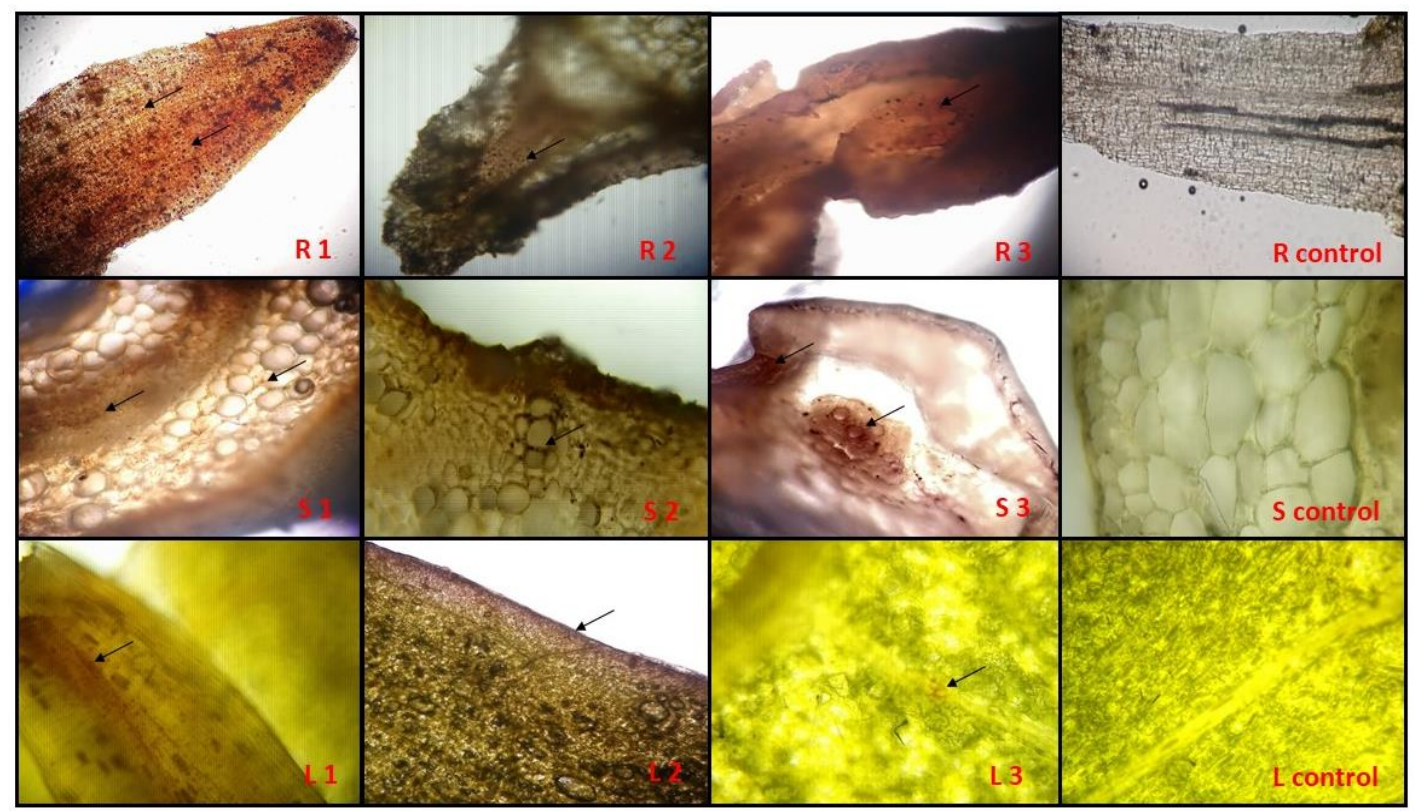

Figure 2. Visualization of $\mathrm{Cd}$ in the roots, the stems, and the leaves of I. glandulifera seedlings exposed to $10 \mathrm{mg} / \mathrm{L} \mathrm{Cd}$ for seven days. R1 to R3 show Cd deposits in the roots, $\mathrm{S} 1$ to $\mathrm{S} 3$ show $\mathrm{Cd}$ in the stems, and L1 to L3 show the leaves. Images R control, S control, and L control are control tissues for roots, stems, and leaves, respectively (these samples were stained with dithizone but not exposed to Cd).

\subsection{Cadmium Trials}

\subsubsection{Soil Characteristics}

The soil utilized was acidic ( $\mathrm{pH}$ of 5.8) and had a relatively high cation exchange capacity (see Table 1). The soil was classified as silt loam with low organic carbon content. The $\mathrm{Cd}$ concentration of the unspiked soil was found to be $0.66 \mathrm{mg} / \mathrm{kg}$.

Table 1. Characteristics of the soil utilized in bioaccumulation trials.

\begin{tabular}{cc}
\hline Soil Properties & Result \\
\hline Texture & Silt Loam \\
Sand & $320 \mathrm{mg} / \mathrm{kg}$ \\
Silt & $640 \mathrm{mg} / \mathrm{kg}$ \\
Clay & $40 \mathrm{mg} / \mathrm{kg}$ \\
$\mathrm{pH}$ (soil:water $=1: 1)$ & 5.8 \\
Organic Carbon $(\%)$ & $2.7 \mathrm{mg} / \mathrm{kg}$ \\
Total Nitrogen & $74 \mathrm{mg} / \mathrm{kg}$ \\
Reactive Phosphorus & $39.3 \mathrm{mg} / \mathrm{kg}$ \\
Potassium & $29.4 \mathrm{mg} / \mathrm{kg}$ \\
Cation Exchange Capacity & $21.7 \mathrm{meq} / 100 \mathrm{~g}$ \\
Cd concentration & $0.66 \mathrm{mg} / \mathrm{kg}$ \\
\hline
\end{tabular}

Average of 3 replicates.

\subsubsection{Plant Growth}

Impatiens glandulifera displayed a high tolerance for $\mathrm{Cd}$, with plants growing up to circa $1.6 \mathrm{~m}$, even when exposed to $150 \mathrm{mg} / \mathrm{kg}$ of Cd. Unlike other phytoaccumulators such as H. annuus, Brassica 
napus, or I. walleriana, even the highest concentration of Cd did not impact the height of the plants (data not shown) or the biomass (DW) produced by the plants $[20,58,59]$. The highest stem biomass recorded was $10.9 \pm 9.3 \mathrm{~g}$, which was higher than T. caerulescens (up to $7.6 \mathrm{~g}$; [60]) and significantly higher than I. walleriana (up to $4.3 \mathrm{~g}$; [20]). There was no significant difference in the plant biomass of the any of the treatments compared with the control ( $p>0.05$, ANOVA). Notably, plants growing in Cd-50 had the highest biomass, achieving a total biomass (DW) of $15 \pm 10 \mathrm{~g}$ (Tables 2 and 3). No outward injury symptoms (e.g., yellow and withered leaves) were observed for any of the plants. Similarly, no signs of outward toxicity were evident for I. walleriana, though H. annus showed visual symptoms of toxicity (light white/yellow spots on leaves) after almost six weeks when exposed to concentrations of up to $15 \mathrm{mg} / \mathrm{kg} \mathrm{Cd}$ [61]. The maintenance of high biomass is considered to be a mechanism of tolerating the toxicity of heavy metals [62]. Indeed, the tall stems of I. glandulifera provide a large surface area over which to accumulate $\mathrm{Cd}$. Though hyperaccumulators such as Arabidopsis halleri and Thlapsi caerulescens possess very high tolerance for $\mathrm{Cd}$, the use of these species is limited due to the limited range of environmental conditions in which they can thrive [63]. As I. glandulifera is an invasive, it may be possible to cultivate this species in a broader range of environmental conditions.

Table 2. Accumulated concentration, biomass (dry weight, DW), total removal (TR), translocation factor (TF), and bioconcentration factor (BCF) of Impatiens glandulifera in Trial 1.

\begin{tabular}{|c|c|c|c|c|c|c|}
\hline $\begin{array}{l}\text { Cadmium } \\
\text { Treatments }\end{array}$ & & $\begin{array}{l}\text { Cadmium Concentration } \\
(\mathrm{mg} / \mathrm{kg})\end{array}$ & Biomass (g) & TR (mg/plant) & $\mathrm{TF}^{*}$ & $\mathrm{BCF}^{* *}$ \\
\hline \multirow{4}{*}{ Control } & Roots & $30 \pm 11.1 \mathrm{a}$ & $1.42 \pm 0.6 \mathrm{a}$ & $0.05 \pm 0.03 \mathrm{a}$ & & \\
\hline & Stems & $32.7 \pm 11.3 a$ & $8.4 \pm 7 \mathrm{a}$ & $0.3 \pm 1.7 \mathrm{a}$ & & \\
\hline & Leaves & $46.2 \pm 32.7 \mathrm{a}$ & $2.5 \pm 1 \mathrm{a}$ & $0.1 \pm 0.1 \mathrm{a}$ & & \\
\hline & Total & & $10.2 \pm 8.8 \mathrm{a}$ & $0.4 \pm 0.2 \mathrm{a}$ & 2.6 & 8.3 \\
\hline \multirow{4}{*}{$20 \mathrm{mg} / \mathrm{kg}$} & Roots & $822 \pm 465 b$ & $1.5 \pm 0.6 \mathrm{a}$ & $1.2 \pm 0.8 \mathrm{~b}$ & & \\
\hline & Stems & $277 \pm 102 b$ & $7.5 \pm 3.4 \mathrm{a}$ & $1.9 \pm 0.8 b$ & & \\
\hline & Leaves & $208 \pm 75 b$ & $2.5 \pm 0.7 \mathrm{a}$ & $0.5 \pm 0.3 b$ & & \\
\hline & Total & & $11.5 \pm 4.1 \mathrm{a}$ & $3.6 \pm 1.5 b$ & 0.7 & 64 \\
\hline \multirow{4}{*}{$40 \mathrm{mg} / \mathrm{kg}$} & Roots & $1030 \pm 375 b$ & $1.3 \pm 0.6 \mathrm{a}$ & $1.4 \pm 0.7 \mathrm{~b}$ & & \\
\hline & Stems & $470 \pm 200 \mathrm{c}$ & $4.8 \pm 2.5 \mathrm{a}$ & $2.3 \pm 1.1 \mathrm{bc}$ & & \\
\hline & Leaves & $325 \pm 213 b$ & $2.1 \pm 0.7 \mathrm{a}$ & $0.7 \pm 0.4 \mathrm{~b}$ & & \\
\hline & Total & & $8.2 \pm 3.5 \mathrm{a}$ & $4.3 \pm 1.8 \mathrm{~b}$ & 0.8 & 45 \\
\hline \multirow{4}{*}{$50 \mathrm{mg} / \mathrm{kg}$} & Roots & $868 \pm 158 b$ & $1.7 \pm 0.8 \mathrm{a}$ & $3.1 \pm 5 b$ & & \\
\hline & Stems & $426 \pm 225 c$ & $10.9 \pm 9.3 \mathrm{a}$ & $4 \pm 3.4 \mathrm{c}$ & & \\
\hline & Leaves & $193 \pm 35 \mathrm{ab}$ & $2.4 \pm 1.1 \mathrm{a}$ & $1.6 \pm 3.1 \mathrm{~b}$ & & \\
\hline & Total & & $15 \pm 10 \mathrm{a}$ & $8.7 \pm 7.8 c$ & 1.2 & 54 \\
\hline
\end{tabular}

Cadmium concentration, biomass, and TR presented as average values \pm SD. TF * $=[\mathrm{Cd}]$ in aerial parts of plant/[Cd] in roots, $B C F^{* *}=[\mathrm{Cd}]$ in harvested plant/[Cd] in soil. The biomass, the accumulation, and the total recovery for stems, roots, leaves, and total plant were analyzed independently. The same lowercase letter indicates no significant difference between $\mathrm{Cd}$ treatments for the same organ $(p<0.05)$.

Table 3. Accumulated concentration, biomass (DW), TR, TF, and BCF of Impatiens glandulifera in Trial 2.

\begin{tabular}{ccccccc}
\hline $\begin{array}{c}\text { Cadmium } \\
\text { Treatments }\end{array}$ & Roots & $\begin{array}{c}\text { Cadmium Concentration } \\
(\mathbf{m g} / \mathbf{k g})\end{array}$ & Biomass $(\mathbf{g})$ & TR (mg/plant) & TF * & BCF ** \\
\hline \multirow{5}{*}{ Control } & $57.2 \pm 19.5 \mathrm{a}$ & $1.2 \pm 0.49 \mathrm{a}$ & $0.07 \pm 0.03 \mathrm{a}$ & \\
\cline { 2 - 6 } & Stems & $44.6 \pm 13.8 \mathrm{a}$ & $5.1 \pm 2.5 \mathrm{a}$ & $0.3 \pm 4.7 \mathrm{a}$ & & \\
\cline { 2 - 7 } & Leaves & $55.2 \pm 19.7 \mathrm{a}$ & $0.9 \pm 0.7 \mathrm{a}$ & $0.06 \pm 0.06 \mathrm{a}$ & & \\
\cline { 2 - 7 } & Flowers & $0 \mathrm{a}$ & $0.23 \pm 0.2 \mathrm{a}$ & $0 \mathrm{a}$ & & $\mathbf{1 1 . 9}$ \\
\cline { 2 - 7 } & Total & & $\mathbf{8 . 2} \pm \mathbf{3 . 8} \mathbf{a}$ & $\mathbf{0 . 4} \pm \mathbf{0 . 2} \mathbf{a}$ & $\mathbf{1 . 7}$ & \\
\hline
\end{tabular}


Table 3. Cont.

\begin{tabular}{|c|c|c|c|c|c|c|}
\hline $\begin{array}{l}\text { Cadmium } \\
\text { Treatments }\end{array}$ & & $\begin{array}{l}\text { Cadmium Concentration } \\
(\mathrm{mg} / \mathrm{kg})\end{array}$ & Biomass (g) & TR (mg/plant) & $\mathrm{TF}^{*}$ & BCF ** \\
\hline \multirow{5}{*}{$60 \mathrm{mg} / \mathrm{kg}$} & Roots & $7089 \pm 3098 b$ & $1.2 \pm 0.3 \mathrm{a}$ & $8.3 \pm 3.3 b$ & & \\
\hline & Stems & $1099 \pm 447 b$ & $7 \pm 2 b$ & $7 \pm 2.7 b$ & & \\
\hline & Leaves & $915 \pm 357 b$ & $0.9 \pm 0.6 \mathrm{a}$ & $0.8 \pm 0.5 b$ & & \\
\hline & Flowers & $98 \pm 40 b$ & $0.2 \pm 2 \mathrm{a}$ & $0.07 \pm 0.04 b$ & & \\
\hline & Total & & $9.2 \pm 2.7 \mathrm{a}$ & $16.1 \pm 5 b$ & 0.3 & 206 \\
\hline \multirow{5}{*}{$90 \mathrm{mg} / \mathrm{kg}$} & Roots & $14,361 \pm 6164 \mathrm{c}$ & $1.3 \pm 0.5 \mathrm{a}$ & $18.9 \pm 9.5 \mathrm{c}$ & & \\
\hline & Stems & $1537 \pm 426 c$ & $6.7 \pm 1.8 \mathrm{ab}$ & $9.3 \pm 3.6 c$ & & \\
\hline & Leaves & $825 \pm 297 b$ & $1.2 \pm 0.8 \mathrm{a}$ & $1.01 \pm 0.7 \mathrm{~b}$ & & \\
\hline & Flowers & $129 \pm 36 b$ & $0.32 \pm 0.3 \mathrm{a}$ & $0.21 \pm 0.09 c$ & & \\
\hline & Total & & $9.3 \pm 2.5 \mathrm{a}$ & $29.2 \pm 11.9 c$ & 0.2 & 236 \\
\hline \multirow{5}{*}{$150 \mathrm{mg} / \mathrm{kg}$} & Roots & $13,000 \pm 4717 c$ & $1.3 \pm 0.5 \mathrm{a}$ & $16.2 \pm 8.1 \mathrm{c}$ & & \\
\hline & Stems & $1562 \pm 572 c$ & $6.2 \pm 3 \mathrm{ab}$ & $8.9 \pm 4.6 \mathrm{bc}$ & & \\
\hline & Leaves & $1052 \pm 416 b$ & $0.9 \pm 0.7 \mathrm{a}$ & $1.05 \pm 1.04 \mathrm{~b}$ & & \\
\hline & Flowers & $136 \pm 88 b$ & $0.26 \pm 0.2 \mathrm{a}$ & $0.13 \pm 0.1 \mathrm{bc}$ & & \\
\hline & Total & & $8.4 \pm 4$ a & $26 \pm 11.9 c$ & 0.2 & 134 \\
\hline
\end{tabular}

Cadmium concentration, biomass, and TR presented as average values $\pm \mathrm{SD} . \mathrm{TF}^{*}=[\mathrm{Cd}]$ in aerial parts of plant/[Cd] in roots, $\mathrm{BCF}^{* *}=[\mathrm{Cd}]$ in harvested plant $/[\mathrm{Cd}]$ in soil. The biomass, the accumulation, and the total recovery for stems, roots, leaves, and total plant were analyzed independently. The same lowercase letter indicates no significant difference between $\mathrm{Cd}$ treatments for the same organ $(p<0.05)$.

\subsubsection{Cadmium Accumulation}

Impatiens glandulifera displayed a similar pattern of accumulation as seen in I. walleriana, whereby $\mathrm{Cd}$ accumulation increased with increasing soil Cd concentrations (up to Cd-90, see Tables 2 and 3) and accumulated in decreasing order of root $>$ stem $>$ leaf [17]. This trend has been observed in other, non-related species (such as soybeans), and it is common that the roots contain the highest levels of $\mathrm{Cd}$, with fruits/seeds containing the least [64]. The highest $\mathrm{Cd}$ concentration was observed in the roots of plants in Cd-90 (14,361 $\pm 6164 \mathrm{mg} / \mathrm{kg}$, Table 2). The roots of I. glandulifera were able to hyperaccumulate impressive concentrations of Cd ( 822 to $14,361 \mathrm{mg} / \mathrm{kg} \mathrm{Cd}$ ) far exceeding those observed in I. walleriana (29.5 to $1900 \mathrm{mg} / \mathrm{kg} \mathrm{Cd;}[20,31])$ and other phytoaccumulator species, e.g., Tagetes patula $(273.77 \mathrm{mg} / \mathrm{kg})$ and Eichhornia crassipes (6103 mg/kg); see Sun et al. [65] and Zhu et al. [66], respectively. There was no difference observed in accumulation by nodes and internodes, and therefore these results were averaged and presented as stems. The highest stem concentration of $\mathrm{Cd}$ was observed in plants from Cd-150 $(1562 \pm 572 \mathrm{mg} / \mathrm{kg})$. The Cd concentration in the stems of plants across all treatments far exceeded the $100 \mathrm{mg} / \mathrm{kg}$ requirement for $\mathrm{Cd}$ hyperaccumulators [22,67]. Though lower than the values of the roots or the stems, the leaves still contained high levels of cadmium, ranging from $193 \pm 35$ to $1052 \pm 416 \mathrm{mg} / \mathrm{kg}$. Interestingly, phytoaccumulators such as Cannabis sativa and Hibiscus cannabinus accumulate very high levels of $\mathrm{Cd}$ in the leaves $[60,65]$. Indeed, the highest levels of $\mathrm{Cd}$ found in C. sativa are in the leaves-contrary to the pattern of accumulation displayed here by I. glandulifera. In one study, H. cannabinus was cultivated in such a way as to collect the leaves as they fell from the plant during the growing season. This consideration may be worthwhile for future I. glandulifera plant trials (particularly field trials) to prevent $\mathrm{Cd}$ leaching back into the environment [63-65]. The flowers of I. glandulifera accumulated Cd up to $136 \mathrm{mg} / \mathrm{kg}$ (see Table 3). The presence of $\mathrm{Cd}$ in the flowers supports the efficient translocation and accumulation observed throughout the plant. However, the presence of $\mathrm{Cd}$ in the flowers also lends the recommendation to harvest the plants before they set flower to avoid interaction with pollinators. 
While there was a large degree of variation in the accumulation of $\mathrm{Cd}$, this has been observed in other species such as T. caerulescens, Chamaecrista fasciculata, poplar clones, and I. walleriana $[2,27,68,69]$. Such a variation can be attributed to a number of variables. For example, the experimental design of these trials placed three plants per pot, and one of these three plants typically grew larger and accumulated higher concentrations. Overall, there was a positive correlation between the biomass (g DW) of the plant and the amount of $\mathrm{Cd}$ it accumulated. This correlation, however, was only significant for the stems (Pearsons's correlation coefficient of 0.297, $p<0.01$, see Figure 3).

Though the plants utilized were grown from seeds collected from a single population of I. glandulifera, the diversity of this species resulting from numerous introduction events and high phenotypic variation (e.g., floral pigmentation, degree of branching) could potentially impact its ability to phytoaccumulate. There are known geographical variations in the phytoaccumulation capacity of T. caerulescens, and different clones of poplar clones were seen to vary "remarkably" in their tolerance and their accumulation of Cd $[27,66]$. Indeed, the white floral morph of I. glandulifera accumulated more $\mathrm{Cd}$ and had a higher biomass in Cd-60 than the purple morph [white morph: $11 \mathrm{~g}$ (DW), $39 \mathrm{mg}$ $\mathrm{Cd}$ total removal. Purple morph: $8 \mathrm{~g}$ (DW), $26 \mathrm{mg}$ Cd total removal]. Due to the uneven number of white and purple flowered plants, statistical significance could not be assessed.

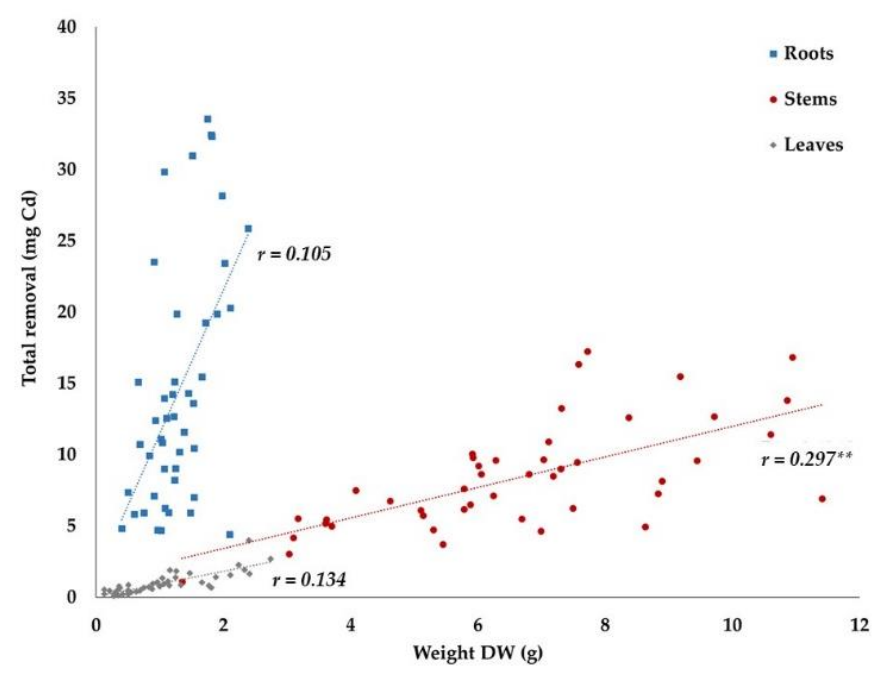

Figure 3. Correlation between the biomass of the plant and the amount of $\mathrm{Cd}$ removed by the plant. Spearman's correlation revealed a positive correlation for all plant tissues with a significant correlation for stems. Pearson's correlation coefficient $(r),{ }^{* *}$ denotes an alpha value of $<0.001$.

\subsubsection{Bioconcentration Factor and Translocation Factor}

The bioconcentration factor, which indicates the efficacy of the plant to accumulate the pollutant in its tissues, was largely greater than unity across all treatments, ranging from 45 to 236 (see Figure 4). Similar to I. glandulifera, other phytoaccumulator species have attained BCFs of up to 100 [70]. Impressively, the roots of the floating macrophyte Azolla pinnata, which is especially good at bioaccumulating $\mathrm{Cd}$ when exposed to levels less than $1 \mathrm{mg} / \mathrm{kg}$, were reported to have a BCF of 24,000 [63]. The translocation factor, which indicates the plant's ability to translocate the pollutant from the roots to the aerial parts of the plant, for I. glandulifera was low-only plants in Cd-50 achieved a TF value greater than unity (see Table 2). However, though TF is a useful measure, it cannot be used in isolation to describe hyperaccumulation [71]. In fact, the aerial parts of I. glandulifera accumulated high levels of $\mathrm{Cd}$, and many times, the $100 \mathrm{mg} / \mathrm{kg}$ requirement and up to $70 \%$ of the total $\mathrm{Cd}$ removed by the plants was located in the aerial parts of the plant (Figure 5B). 


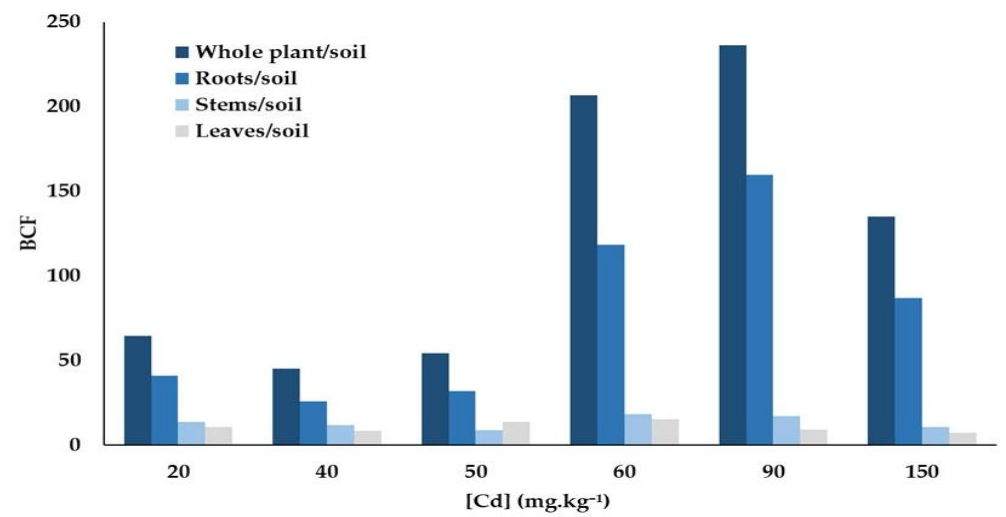

Figure 4. Bioconcentration factors for I. glandulifera across all Cd concentrations. The concentration of $\mathrm{Cd}$ in all parts of the plant exceed that of the soil.
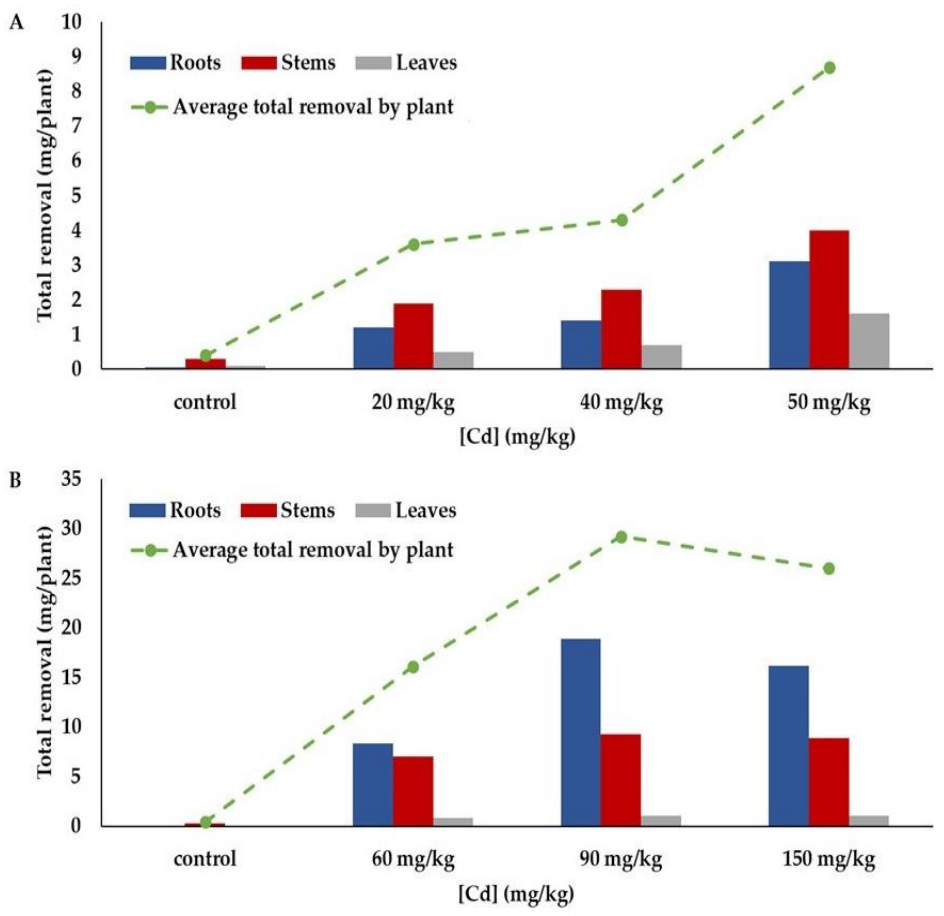

Figure 5. Total removal of Cd per I. glandulifera plant. Trial one is presented in A, and trial two is presented in $\mathrm{B}$. The amount of $\mathrm{Cd}$ removed by the roots, the stems, and the leaves of both trials are represented in the bar charts. A linear increase was observed in the total amount of Cd accumulated by a whole plant in trial 1 (A) and up to $90 \mathrm{mg} / \mathrm{kg}$ Cd in trial two (B). Values represent average ( $n=15)$. Statistical analyses of total removal for trials one and two can be found in Tables 2 and 3, respectively.

Interestingly, plants of I. glandulifera grown in the control soil achieved BCF and TF values of above unity. Though the BCF value was considerably lower for the control than the treatments, the highest TF value was attained by the control plants. Although the control soil was not spiked with $\mathrm{Cd}$, it was found nonetheless to contain very marginal levels of $\mathrm{Cd}(0.66 \mathrm{mg} / \mathrm{kg}$ of $\mathrm{Cd})$. Though many phytoaccumulator plants such as Brassica juncea or Panicum virgatum are not effective at removing $\mathrm{Cd}$ when soil levels are low, there are many species that show great potential to be used to bioaccumulate $\mathrm{Cd}$ in soils with levels as low as $0.33 \mathrm{mg} / \mathrm{kg}$. These species include T. caerulescens, Hibiscus cannabinus, Azolla pinnata, Lemna minor, Vertiever grass, rice, maize, and sugar beet $[63,64,70,72]$. Indeed, even $H$. annus grown in control soil and not treated with $\mathrm{Cd}$ was found to accumulate $\mathrm{Cd}$, though at a lesser extent than the $\mathrm{Cd}$ treatments [61]. 
Interestingly, some plants have been observed to release exudates, which increase the solubility of heavy metals, facilitating their uptake even at low concentrations [73]. Considering that I. glandulifera has been shown to release allelochemicals that impact both fungi and insects, future research may consider investigating if I. glandulifera and other potential phytoaccumulator invasive plants utilize such a strategy $[74,75]$.

Though the control plants did not achieve the requisite $100 \mathrm{mg} / \mathrm{kg} \mathrm{Cd}$ in their shoots, the BCF and the TF factors were both above unity, and an average total recovery of $0.4 \mathrm{mg} / \mathrm{plant}$ of $\mathrm{Cd}$ was attained. This property (accumulating in the presence of low levels of $\mathrm{Cd}$ ) is as intriguing as the high tolerance of I. glandulifera towards the toxicity of $\mathrm{Cd}$. These results warrant further investigation, and future trials ought to assess the accumulation of $\mathrm{Cd}$ at both low and even higher levels.

This research, through pot trials, enables an initial assessment of tolerance and suitability for bioremediation. However, the capacity of I. glandulifera to accumulate $\mathrm{Cd}$ of non-spiked soil highlights the importance of field trials to truly establish the feasibility of utilizing I. glandulifera as a phytoremediator. The efficacy of $T$. caerulescens is known to vary significantly in the field, as accumulation is influenced by a number of factors [68]. Therefore, field trials are necessary to allow conclusions to be made regarding the efficacy and the applicability of I. glandulifera as a phytoremediator.

\subsubsection{Total Removal}

In trial one, there was a linear increase in the total removal of $\mathrm{Cd}$ (Figure 5A); this linear trend was observed in trial two up to Cd-90 (Figure 5B). The total Cd removed by a single plant exposed to $\mathrm{Cd}$ across the two trials varied between $3.6 \pm 1.5 \mathrm{mg}$ to $29.2 \pm 11.9 \mathrm{mg}$ (Figure 5). In comparison, the largest amount of Cd removed by a single plant of I. walleriana (grown in $80 \mathrm{mg} / \mathrm{kg} \mathrm{Cd}$ ) was $3.4 \mathrm{mg}$ [20]. The largest amount of $\mathrm{Cd}$ was located in the stems of plants from the treatments ranging from $\mathrm{Cd}-20$ to $\mathrm{Cd}-60$ (Figure $5 \mathrm{~A}$ ) and in the roots of plants from treatments ranging from Cd-90 and Cd-150 (Figure 5B). The Cd located in the stems of Cd-20 to Cd-60 plants represented between 43 to $53 \%$ of the total $\mathrm{Cd}$ removed by the plant. Whereas for $\mathrm{Cd}-90$ and $\mathrm{Cd}-150$ plants, the level of $\mathrm{Cd}$ found in the roots was approximately twice the level of that found in the stems of the plant and represented more than $60 \%$ of the total Cd removed by the plant (Figure 5). The ability to translocate $\mathrm{Cd}$ to the aboveground parts is critical for efficacious phytoremediation. However, species with high tolerance and BCF values that cannot effectively translocate $C d$ to the stems are often useful for phytostabilization $[63,76]$.

In trial two, the total removal of Cd did not vary significantly after $60 \mathrm{mg} / \mathrm{kg}$ (see Table 3 and Figure 5B). In future research, it would be interesting to establish the extent of tolerance of I. glandulifera for $\mathrm{Cd}$, and indeed other heavy metals, in order to examine the concentration at which maximum efficacy of accumulation and translocation occurs. It is important to note that the results herein presented are from two accumulation trials of different concentrations and durations. This research provides a strong indication that I. glandulifera has a high tolerance for $\mathrm{Cd}$ and appears to be a very promising potential hyperaccumulator of $\mathrm{Cd}$. Nonetheless, further experimental work is required before concluding that I. glandulifera is a Cd hyperaccumulator. Future research should consider taking into account the duration of accumulation. Impatiens glandulifera appears to uptake Cd rapidly (see visualization of $\mathrm{Cd}$ ), and it is important to examine the optimum duration of accumulation trials, which is likely to differ depending on environmental conditions.

\subsection{Germination}

\subsubsection{In Vitro Seed Germination}

One of the limiting factors of phytoremediation is that germination in heavily contaminated soil is typically poor, as seedlings of many plants are often more sensitive to metal pollution than mature plants [4]. Impatiens glandulifera was found to possess an unprecedented level of hypertolerance for the toxicity of $\mathrm{Cd}$, with seeds germinating in the presence of up to $40 \mathrm{mg} / \mathrm{mL}$ of $\mathrm{Cd}$ under vitro conditions (equivalent to $40,000 \mathrm{mg} / \mathrm{kg} \mathrm{Cd}$, see Figure 6). Indeed, there was no significant difference 
in the germination of seeds exposed to $1 \mathrm{mg} / \mathrm{mL}$ (equivalent to $1000 \mathrm{mg} / \mathrm{kg}$ ) compared to the control $(0 \mathrm{mg} / \mathrm{mL}, p<0.05)$. Though there was a statistically significant decrease in germination passed this concentration $(44 \%, 18 \%, 8 \%$, and $0 \%$ for $10,20,40$, and $50 \mathrm{mg} / \mathrm{mL}$, respectively, $p<0.05)$, noteworthy is the ability for the seeds to retain a $44 \%$ germination rate at $10 \mathrm{mg} / \mathrm{mL}$ (equivalent to $10,000 \mathrm{mg} / \mathrm{kg}$ ). This suggests that I. glandulifera could be utilized in even the most heavily polluted regions as a phytoaccumulator. Given that each I. glandulifera plant can produce up to 2500 seeds, this fast growing annual could be grown with ease to rapidly decrease Cd levels [33]. The invasive grass Cynodon dactylon was also shown to germinate when exposed to high levels of $\mathrm{Cd}(30 \%$ of seeds germinated

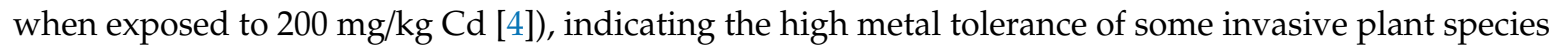
and their potential application in phytoremediation.

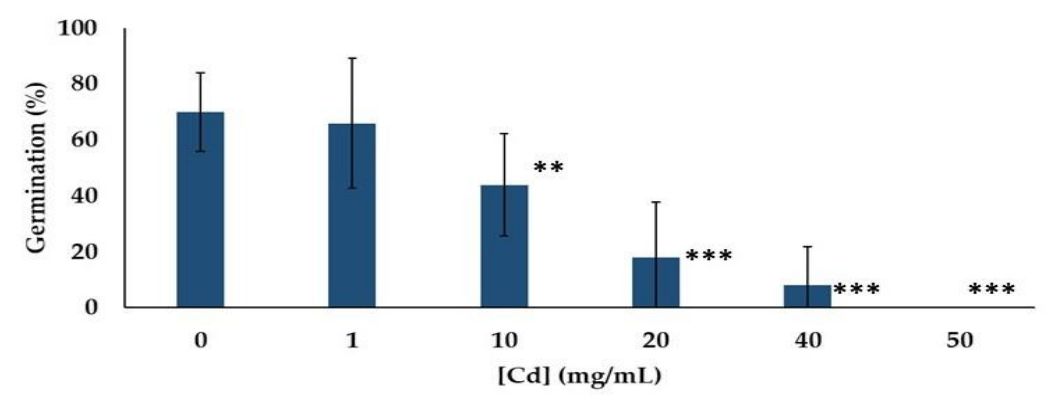

Figure 6. Germination of I. glandulifera seedlings in the presence of Cd. A significant decrease in germination was observed from $10 \mathrm{mg} / \mathrm{mL} \mathrm{Cd}$. Significance was established as alpha value of * $\leq 0.05$, ${ }^{* *} \leq 0.01,{ }^{* *} \leq 0.001$. Average values $(n=50), \pm$ standard deviation.

\subsubsection{Pollen Germination}

Pollen has been suggested as a useful bioindicator for heavy metal contamination, as pollen has been observed to be more sensitive to pollutants than vegetative parts of the plant. Indeed, it has been observed that the germination of pollen of several species is strongly inhibited by low levels of Cd $[7,77]$. Therefore, the ability of pollen to germinate was established for samples taken from I. glandulifera plants (control plants and Cd-20 to Cd-150 plants). No difference in the ability to germinate was observed, with pollen germinating across all treatments. This indicates that even levels of $\mathrm{Cd}$ as high as $150 \mathrm{mg} / \mathrm{kg}$ do not impact the ability of this species to reproduce, highlighting the strong tolerance of I. glandulifera towards Cd.

\section{Conclusions}

An ideal hyperaccumulator ought to be fast growing, easy to harvest, show resistance to pests and disease and tolerance towards toxicity, and possess the ability to rapidly uptake, translocate, and bioconcentrate the toxin $[6,16,44,70]$. Impatiens glandulifera is a fast-growing plant resistant to pests and disease outside of its native range in the Himalayas [78]. This research indicates that I. glandulifera possesses a high tolerance of $\mathrm{Cd}$ [plants grew to $1.6 \mathrm{~m}$ with no sign of toxicity, and seeds germinated (in vitro) in the presence of $1000 \mathrm{mg} / \mathrm{kg} \mathrm{Cd}$ ] and is therefore deserving of future research to ascertain if this species can be classified as a hyperaccumulator. Impatiens glandulifera accumulated and translocated $\mathrm{Cd}$ in exceedingly high concentrations, removing up to $29 \mathrm{mg}$ of $\mathrm{Cd}$ per plant. If I. glandulifera can replicate these results in field trials, this invasive may prove to be very beneficial—even in the face of its potentially limiting factors (invasive status, annual flowering plant, shallow roots). The fast growth and the apparent ability to rapidly uptake $\mathrm{Cd}$ may facilitate effective phytoaccumulation in a relatively short period, enabling the plants to be removed before setting seed and spreading. Though it is preferable for hyperaccumulators to have deep roots (e.g., poplar and willow), the shallow roots of I. glandulifera make it feasible to easily harvest the entire plant-something that is not typically possible —enabling the recovery of all the accumulated $\mathrm{Cd}[6,70,79]$. 
Impatiens walleriana was also found to accumulate mercury, though at a lower capacity than Cd. Therefore, there may be potential for I. glandulifera to act as a phytoaccumulator for other heavy metals [67]. More trials are needed to further assess the capacity of I. glandulifera to tolerate and accumulate $\mathrm{Cd}$ and other heavy metals. In particular, bioaccumulation trials in the field using naturally contaminated soil will be an important next step in determining the full potential of I. glandulifera.

Author Contributions: Conceptualization, C.P. and S.C.; methodology, C.P. and S.C.; validation, S.C.; formal analysis, S.C. and C.P.; investigation, S.C.; resources, S.C.; data curation, S.C.; writing-original draft preparation, S.C.; writing-review and editing, C.P., G.C., B.O. and A.-M.E.; visualization, S.C., C.P. and G.C.; supervision, C.P., G.C., A.-M.E. and B.O.; project administration, C.P., S.C., G.C.; funding acquisition, C.P.

Funding: This research was funded by President's Research Fellowship Scholarship, grant number PES1219, from the Institute of Technology Carlow.

Acknowledgments: The authors wish to thank the support offered by EnviroCore and the Department of Science and Health in the Institute of Technology Carlow. The authors would also like to express their gratitude to the reviewers for their insightful contributions which improved this paper. A special thank you to John Byrne of Carlow I.T. for his help with AAS Spectrometry.

Conflicts of Interest: The authors declare no conflict of interest.

\section{References}

1. Liu, Y.; Yang, Y.; Li, C.; Ni, X.; Ma, W.; Wei, H. Assessing soil metal levels in an industrial environment of northwest china and the phytoremediation potential of its native plants. Sustainability 2018, 10, 2686. [CrossRef]

2. Henson, T.M.; Cory, W.; Rutter, M.T. Extensive Variation in Cadmium Tolerance and Accumulation among Populations of Chamaecrista fasciculate. PLoS ONE 2013, 8, e63200. [CrossRef] [PubMed]

3. Li, J.-T.; Baker, A.J.M.; Ye, Z.-H.; Wang, H.-B.; Shu, W.-S. Phytoextraction of Cd-contaminated soils: Current status and future challenges. Crit. Rev. Environ. Sci. Technol. 2012, 42, 2113-2152. [CrossRef] [PubMed]

4. Del Rosario Delgado-Caballero, M.; Alarcón-Herrera, M.T.; Valles-Aragón, M.C.; Melgoza-Castilo, A.; Ojeda-Barrios, D.L.; Leyva-Chávez, A. Germination of Bouteloua dactyloides and Cynodon dactylon in a multi-polluted soil. Sustainability 2017, 9, 81. [CrossRef]

5. Science Communication Unit, University of the West of England, Bristol. Science for Environment Policy In-depth Report: Soil Contamination: Impacts on Human Health. Report produced for the European Commission DG Environment, September 2013. Available online: https://ec.europa.eu/search/?queryText= Soil+Contamination\%3A+Impacts+on+Human+Health\&query_source=ENVSCPOL\&filterSource= ENVSCPOL\&swlang=en\&more_options_language=en\&more_options_f_formats=\&more_options_date= (accessed on 12 September 2019).

6. Ali, H.; Khan, E.; Sajad, M.A. Phytoremediation of heavy metals- Concepts and applications. Chemosphere 2013, 91, 869-881. [CrossRef] [PubMed]

7. Xiong, Z.-T.; Peng, Y.-H. Response of pollen germination and tube growth to cadmium with special reference to low concentration exposure. Ecotoxicol. Environ. Saf. 2001, 48, 51-55. [CrossRef] [PubMed]

8. Brown, S.L.; Chaney, R.L.; Angle, J.S.; Baker, A.J.M. Phytoremediation potential of Thlaspi caerulescens and bladder campion for zinc- and cadmium-contaminated soil. J. Environ. Qual. 1994, 23, 1151-1157. [CrossRef]

9. Pan, J.; Plant, J.A.; Voulvoulis, N. Cadmium levels in Europe: Implications for human health. Environ. Geochem. Health 2010, 32, 1-12. [CrossRef] [PubMed]

10. Simmons, R.W.; Pongsakul, P.; Saiyasitpanich, D.; Klinphoklap, S. Elevated levels of cadmium and zinc in paddy soils and elevated levels of cadmium in rice grain downstream of a zinc mineralized area in Thailand: Implication for public health. Environ. Geochem Health 2005, 27, 501-511. [CrossRef]

11. World Health Organisation, Geneva. Cadmium in Drinking-Water. Background Document for Development of WHO Guidelines for Drinking-Water Quality. 2011. Available online: https://www.who.int/water sanitation_health/dwq/chemicals/cadmium.pdf (accessed on 12 September 2019).

12. World Health Organisation, Geneva. Cadmium-Environmental Aspects. 1992. Environmental Health Criteria 135. Available online: http://www.inchem.org/documents/ehc/ehc/ehc134.htm (accessed on 12 September 2019). 
13. Idrees, N.; Tabassum, B.; Abd_Allah, E.F.; Hashem, A.; Sarah, R.; Hashim, M. Groundwater contamination with cadmium concentrations in some West U.P. Regions, India. Saudi J. Biol. Sci. 2018, 25, 1365-1368. [CrossRef]

14. Deng, H.; Ye, Z.H.; Wong, M.H. Accumulation of lead, zinc, copper and cadmium by 12 wetland plant species thriving in metal-contaminated sites in China. Environ. Pollut. 2004, 132, 29-40. [CrossRef] [PubMed]

15. Meng, H.; Hua, S.; Shamsi, I.H.; Jilani, G.; Li, Y.; Jiang, L. Cadmium-induced stress on the seed germination and seedling growth of Brassica napus L., and its alleviation through exogenous plant growth regulators. Plant Growth Regul. 2009, 58, 47-59. [CrossRef]

16. Ghosh, M.; Singh, S.P. A review on phytoremediation of heavy metals and utilization of it's by it's products. Asian J. Energ. Environ. 2005, 6, 214-231.

17. Lai, H.-Y. Subcellular distribution and chemical forms of cadmium in Impatiens walleriana in relation to it phytoextraction potential. Chemosphere 2015, 138, 370-376. [CrossRef] [PubMed]

18. Padmavathiamma, P.K.; Li, L.Y. Phytoremediation technology: Hyper-accumulation metals in plants. Water Air Soil Pollut. 2007, 184, 105-126. [CrossRef]

19. Dixit, R.; Wasiullah; Malaviya, D.; Pandiyan, K.; Singh, U.B.; Sahu, A.; Shukla, R.; Singh, B.P.; Rai, J.P.; Sharma, P.K.; et al. Bioremediation of heavy metals from soil and aquatic environment: An overview of principles and criteria of fundamental processes. Sustainability 2015, 7, 2189-2212. [CrossRef]

20. Wei, J.-L.; Lai, H.-Y.; Chen, Z.-S. Chelator effects on bioconcentration and translocation of cadmium by hyperaccumulators, Tagetes patula and Impatiens walleriana. Ecotoxicol. Environ. Saf. 2012, 84, 173-178. [CrossRef] [PubMed]

21. Yoon, J.; Cao, X.; Zhou, Q.; Ma, L.Q. Accumulation of $\mathrm{Pb}, \mathrm{Cu}$, and $\mathrm{Zn}$ in native plants growing on a contaminated Florida site. Sci. Total Environ. 2006, 368, 456-464. [CrossRef]

22. Baker, A.J.M.; McGrath, S.P.; Reeves, R.D.; Smith, J.A.C. Metal hyperaccumulator plants: A review of the ecology and physiology of a biological resource for phytoremediation of polluted soils. In Phytoremediation of Contaminated Soil and Water; Bañuelos, T.N., Ed.; CRC Press: Boca Raton, FL, USA, 2001; pp. 85-107.

23. Brooks, R.R.; Lee, J.; Reeves, R.D.; Jaffrre, T. Detection of nickeliferous rocks by analysis of herbarium specimens of indicator plants. J. Geochem. Explor. 1977, 7, 49-57. [CrossRef]

24. Liu, J.-N.; Zhou, Q.-X.; Sun, T.; Ma, L.Q.; Wang, S. Growth responses of three ornamental plants to Cd-Pb stress and their metal accumulation characteristics. J. Hazard. Mater. 2008, 151, 261-267. [CrossRef]

25. Wu, M.; Luo, Q.; Liu, S.; Zhao, Y.; Long, Y.; Pan, Y. Screening ornamental plants to identify potential Cd hyperaccumulators for bioremediation. Ecotoxicol. Environ. Saf. 2018, 162, 35-41. [CrossRef] [PubMed]

26. Zhuang, P.; Yang, Q.W.; Wang, H.B.; Shu, W.S. Phytoextraction of heavy metals by eight plant species in the field. Water Air Soil Pollut. 2007, 184, 235-242. [CrossRef]

27. Zacchini, M.; Pietrini, F.; Mugnozza, G.S.; Iori, V.; Pietrosanti, L.; Massacci, A. Metal tolerance, accumulation and translocation in poplar and willow clones treated with cadmium in hydroponics. Water Air Soil Pollut. 2009, 197, 23-24. [CrossRef]

28. Akhter, M.F.; Omelon, C.R.; Gordon, R.A.; Moser, D.; Macfie, S. Chemical speciation of cadmium in the roots of barley and lettuce. Environ. Exper. Bot. 2014, 43, 10-196. [CrossRef]

29. Lai, H.-Y. Effects of leaf area and transpiration rate on accumulation and compartmentalization of cadmium in Impatiens walleriana. Water Air Soil Pollut. 2014, 226, 2246. [CrossRef]

30. Boominathan, R.; Doran, P.M. Cadmium tolerance and antioxidative defences in hairy roots of the cadmium hyperaccumulator, Thlaspi caerulescens. Biotechnol. Bioeng. 2002, 83, 158-167. [CrossRef] [PubMed]

31. Lai, H.-Y.; Cai, M.-C. Effects of extended growth periods on subcellular distribution, chemical forms, and the translocation of cadmium in Impatiens walleriana. Int. J. Phytoremediation. 2016, 18, 228-234. [CrossRef] [PubMed]

32. Lin, C.-C.; Lai, H.-Y.; Chen, Z.-S. Bioavailability assessment and accumulation by five garden flower species grown in artificially cadmium-contaminated soils. Int. J. Phytoremediation 2010, 12, 454-467. [CrossRef] [PubMed]

33. Beerling, D.J.; Perrins, J.M. Impatiens glandulifera Royle (Impatiens roylei Walp.). J. Ecol. 1993, 81, $367-382$. [CrossRef] 
34. Clements, D.R.; Feenstra, K.R.; Jones, K.; Staniforth, R. The biology of invasive alien plants in Canada. 9. Impatiens glandulifera Royle. Can. J. Plant Sci. 2008, 88, 403-417. [CrossRef]

35. Skálová, H.; Havlíčková, V.; Pyšek, P. Seedling traits, plasticity and local differentiation as strategies of invasive species of Impatiens in central Europe. Ann. Bot. 2012, 110, 1429-1438. [CrossRef] [PubMed]

36. Sakai, A.K.; Allendorf, F.W.; Holt, J.S.; Lodge, D.M.; Molofsky, J.; With, K.A.; Baughman, S.; Cabin, R.J.; Cohen, J.E.; Ellstrand, N.C.; et al. The population biology of invasive species. Annu. Rev. Ecol. Syst. 2001, 32, 305-332. [CrossRef]

37. Vervoort, A.; Cawoy, V.; Jacquemart, A.-L. Comparative reproductive biology in co-occurring invasive and non-invasive Impatiens species. Int. J. Plant Sci. 2011, 172, 366-377. [CrossRef]

38. Hejda, M.; Pyšek, P. What is the impact of Impatiens glandulifera on species diversity of invaded riparian vegetation? Biol. Conserv. 2006, 132, 143-152. [CrossRef]

39. Tanner, R.A.; Gange, A.C. The impact of two non-native plant species on native flora performance: Potential implications for habitat restoration. Plant. Ecol. 2013, 214, 423-434. [CrossRef]

40. Eid, E.M.; Shaltout, K.H.; Moghanm, F.S.; Youssef, M.S.G.; El-Mohsnawy, E.; Haroun, S.A. Bioaccumulation and translocation of nine heavy metals by Eichhornia crassipes in Nile Delta, Egypt: Perspectives for phytoremediation. Int. J. Phytoremediation 2019, 21, 1-10. [CrossRef] [PubMed]

41. Abbas, A.M.; Abd-Elmabod, S.K.; El-ashry, S.M.; Soliman, W.S.; El-Tayeh, N.; Castillo, J.M. Capability of the invasive tree Proposis glandulosa Torr. to remediate soil treated with sewage sludge. Sustainability 2019, 11, 2711. [CrossRef]

42. Padley, V.C. Invasive species based efficient green technology for phytoremediation of fly ash deposits. J. Geochem. Explor. 2013, 123, 13-18. [CrossRef]

43. Hoagland, D.R.; Snyder, W.C. Nutrition of strawberry plant under controlled conditions. J. Am. Soc Hortic Sci. 1933, 30, 288-294.

44. Wang, A.S.; Angle, J.S.; Chaney, R.L.; Delorme, T.A.; Reeves, R.D. Soil pH effects on uptake of Cd and Zn by Thlaspi caerulescens. Plant Soil 2006, 281, 325-337. [CrossRef]

45. Lombi, E.; Zhao, F.J.; Dunham, S.J.; McGrath, S.P. Phytoremediation of heavy metal-contaminated soils: Natural hyperaccumulation versus chemically enhanced phytoextraction. J. Environ. Qual. 2001, 30, 1919-1926. [CrossRef] [PubMed]

46. Clabeaux, B.L.; Navarro, D.A.G.; Aga, D.S.; Bisson, M.A. Cd tolerance and accumulation in the aquatic macrophyte, Chara australis: Potential use for charophytes in phytoremediation. Environ. Sci. Technol. 2011, 45, 5332-5338. [CrossRef] [PubMed]

47. Shirazi, M.A.; Boersma, L. A unifying quantitative analysis of soil texture. SSSA 1984, 48, 142-147. [CrossRef]

48. Thomas, G.W. Soil pH and soil acidity. In Methods of Soil Analysis, Part 3, Chemical Methods, 1st ed.; Page, D.L., Helmke, P.A., Loeppert, R.H., Soltanpour, P.N., Tabatabai, M.A., Johnston, C.T., Sumner, M.E., Eds.; Soil Science Society of America, Inc.: Madison, WI, USA, 1996; pp. 475-490.

49. Jackson, M.L. Soil Chemical Analysis. J. Plant Nutr. Soil Sci. 1958, 85, 251-252.

50. Walkley, A.; Black, I.A. An examination of the Degtjareff method for determining soil organic matter and a proposed modification of the chromic acid titration method. Soil Sci. 1934, 37, 29-38. [CrossRef]

51. HACH, Laton Total Nitrogen Cuvette Test $20-100$ mg/L TNb, 25 Tests. Available online: https://ie.hach.com/ asset-get.download.jsa?id=25593604089 (accessed on 12 September 2019).

52. HACH, Phosphorus, Reactive (Orthophosphate) Molybdovanadate Method 8114, Test 'N Tube ${ }^{\mathrm{TM}}$ Vials. Available online: https://ie.hach.com/asset-get.download.jsa?id=7639983833 (accessed on 12 September 2019).

53. HACH, Potassium, Tetraphenylborate Method 8049, Spectrophotometer, Powder Pillows. Available online: https://ie.hach.com/asset-get.download.jsa?id=7639983843 (accessed on 12 September 2019).

54. Perglová, I.; Pergl, J.; Skálová, H.; Moravcová, L.; Jarošík, V.; Pyšek, P. Differences in germination and seedling establishment of alien and native Impatiens species. Preslia 2009, 81, 357-375.

55. Hussein, N. In vitro manipulation of Impatiens glandulifera pollen for transporting extracellular substances to the embryo sac. Curr. Res. J. Biol. Sci. 2014, 6, 66-70. [CrossRef]

56. Peterson, R.; Slovin, J.P.; Chen, C. A simplified method for differential staining of aborted and non-aborted pollen grains. Int. J. Plant Biol. 2010, 1, 66-69. [CrossRef] 
57. Milner, M.J.; Kochian, L.V. Investigating heavy-metal hyperaccumulation using Thlaspi caerulescens as a model system. Ann. Bot. 2008, 102, 3-13. [CrossRef]

58. Selvam, A.; Wong, J.W.C. Phytochelatin systhesis and cadmium uptake of Brassica napus. Environ. Technol. 2008, 29, 765-773. [CrossRef]

59. Alaboudi, K.A.; Ahmed, B.; Brodie, G. Phytoremediation of $\mathrm{Pb}$ and $\mathrm{Cd}$ contaminated soils by using sunflower (Helianthus annuus) plant. AOAS 2018, 63, 123-127. [CrossRef]

60. Epelde, L.; Becerril, J.M.; Kowalchuk, G.A.; Deng, Y.; Zhou, J.; Garbisu, C. Impact of metal pollution and Thlaspi caerulescens growth soil microbial communities. Appl. Environ. Microbiol. 2010, 76, 7843-7853. [CrossRef] [PubMed]

61. Mani, D.; Sharma, B.; Kumar, C. Phytoaccumulation, interaction, toxicity and remediation of cadmium from Helianthus annuus L. (sunflower). Bull. Environ. Contam. Toxicol. 2007, 79, 71-79. [CrossRef] [PubMed]

62. Pietrini, F.; Zacchini, M.; Iori, V.; Pietrosanti, L.; Bianconi, D.; Massacci, A. Screening of poplar clones for cadmium phytoremediation using photosynthesis, biomass and cadmium content analyses. Int. J. Phytoremediation 2010, 12, 105-120. [CrossRef] [PubMed]

63. Mahajan, P.; Kaushal, J. Role of phytoremediation in reducing cadmium toxicity in soil and water. J. Toxicol. 2018, 2018, 1-16. [CrossRef]

64. Alkorta, I.; Hernández-Allica, J.; Becerril, J.M.; Amezaga, I.; Albizu, I.; Garbisu, C. Recent findings on the photoremediation of soils contaminated with environmentally toxic heavy metals and metalloids such as zinc, cadmium, lead and arsenic. Rev. Environ. Sci. Biotechnol. 2004, 3, 71-90. [CrossRef]

65. Baker, A.J.M.; Brooks, R.R. Terrestrial higher plants which hyperaccumulate metallic elements-A review of their distribution, ecology and phytochemistry. Biorecovery 1989, 1, 81-126.

66. Sun, R.; Sun, Q.; Wang, R.; Cao, L. Cadmium accumulation and main rhizosphere characteristics of seven French marigold (Tagetes patula L.) cultivars. Int. J. Phytoremediation 2018, 20, 1171-1178. [CrossRef]

67. Zhu, Y.L.; Zayed, A.M.; Qian, J.-H.; de Souza, M.; Terry, N. Phytoaccumulation of trace elements by wetland plants: II. Water hyacinth. J. Environ. Qual. 1999, 28, 339-344. [CrossRef]

68. Zhao, F.J.; Lombi, E.; McGrath, S.P. Assessing the potential for zinc and cadmium phytoremediation with the hyperaccumulator Thlaspi caerulescens. Plant Soil 2003, 249, 37-43. [CrossRef]

69. Pant, P.; Allen, M.; Tansel, B. Mercury Uptake and Translocation in Impatiens walleriana plants grown in the contaminated soil from oak ridge. Int. J. Phytoremediation 2010, 13, 168-176. [CrossRef]

70. Sun, Y.; Zhou, Q.; Wang, L.; Liu, W. Cadmium tolerance and accumulation characteristics of Bidens pilosa L. as a potential Cd-hyperaccumulator. J. Hazard. Mater. 2009, 161, 808-814. [CrossRef] [PubMed]

71. Van der Ent, A.; Baker, A.J.M.; Reeves, R.D.; Pollard, A.J.; Schat, H. Hyperaccumulators of metal and metalloid trace elements: Facts and fiction. Plant. Soil 2013, 362, 319-334. [CrossRef]

72. Shrestha, P.; Bellitürk, K.; Görres, J.H. Phytoremediation of heavy metal-contaminated soil by switchgrass: A comparative study utilizing different composts and coir fiber on pollution remediation, plant productivity, and nutrient leaching. IJERPH 2019, 16, 1261. [CrossRef] [PubMed]

73. Ishikawa, S.; Noriharu, A.E.; Murakami, M.; Wagatsuma, T. Is Brassica juncea a suitable plant for phytoremediation of cadmium in soils with moderately low cadmium contamination?-Possibility of using other plant species for Cd-phytoextraction. J. Soil Sci. Plant Nutr. 2006, 52, 32-42. [CrossRef]

74. Ruckli, R.; Rusterholz, H.-P.; Baur, B. Invasion of Impatiens glandulifera affects terrestrial gastropods by altering microclimate. Acta Oecol. 2013, 47, 16-23. [CrossRef]

75. Ruckli, R.; Rusterholz, H.-P.; Baur, B. Invasion of an annual exotic plant into deciduous forests suppresses arbuscular mycorrhiza symbiosis and reduces performance of sycamore maple saplings. Forest Ecol. Manag. 2014, 318, 285-293. [CrossRef]

76. Nirola, R.; Megharaj, M.; Palanisami, T.; Aryal, R.; Venkateswarlu, K.; Naidu, R. Evaluation of metal uptake factors of native trees colonizing an abandoned copper mine-A quest for phytostabilization. J. Sustain. Min. 2015, 14, 115-123. [CrossRef]

77. Conti, M.E.; Botrè, F. Honeybees and their products as potential bioindicators of heavy metals contamination. Environ. Monit. Assess. 2001, 69, 267-282. [CrossRef] 
78. Tanner, R.A. A review on the potential for the biological control of the invasive weed, Impatiens glandulifera in Europe. In Plant Invasions: Human Perception, Ecological Impacts and Management; Tokarska-Guzik, T., Brock, J.H., Brundu, G., Child, L., Daehler, C.C., Pyšek, P., Eds.; Backhuys Publishers: Leiden, The Netherlands, 2008; pp. 343-354.

79. Seo, B.-H.; Kim, H.S.; Kuppusamy, S.; Kim, K.-H.; Kim, K.-R. Enhanced nitrogen and phosphorus removal by woody plants with deep-planting technique for the potential environmental management of carcass burial sites. Sustainability 2017, 9, 155. [CrossRef]

(C) 2019 by the authors. Licensee MDPI, Basel, Switzerland. This article is an open access article distributed under the terms and conditions of the Creative Commons Attribution (CC BY) license (http://creativecommons.org/licenses/by/4.0/). 